\title{
Effects of Aedes aegypti salivary components on dendritic cell and lymphocyte biology
}

Bruna Bizzarro ${ }^{1}$, Michele S Barros', Ceres Maciel' ${ }^{1}$, Daniele I Gueroni ${ }^{1}$, Ciro N Lino ${ }^{1}$, Júlia Campopiano², Michalis Kotsyfakis ${ }^{3}$, Gustavo P Amarante-Mendes ${ }^{2,4}$, Eric Calvo ${ }^{5}$, Margareth L Capurro ${ }^{6,7}$ and Anderson Sá-Nunes ${ }^{1,7^{*}}$

\begin{abstract}
Background: Saliva is a key element of interaction between hematophagous mosquitoes and their vertebrate hosts. In addition to allowing a successful blood meal by neutralizing or delaying hemostatic responses, the salivary cocktail is also able to modulate the effector mechanisms of host immune responses facilitating, in turn, the transmission of several types of microorganisms. Understanding how the mosquito uses its salivary components to circumvent host immunity might help to clarify the mechanisms of transmission of such pathogens and disease establishment.
\end{abstract}

Methods: Flow cytometry was used to evaluate if increasing concentrations of $A$. aegypti salivary gland extract (SGE) affects bone marrow-derived DC differentiation and maturation. Lymphocyte proliferation in the presence of SGE was estimated by a colorimetric assay. Western blot and Annexin $V$ staining assays were used to assess apoptosis in these cells. Naive and memory cells from mosquito-bite exposed mice or OVA-immunized mice and their respective controls were analyzed by flow cytometry.

Results: Concentration-response curves were employed to evaluate A. aegypti SGE effects on DC and lymphocyte biology. DCs differentiation from bone marrow precursors, their maturation and function were not directly affected by A. aegypti SGE (concentrations ranging from 2.5 to $40 \mu \mathrm{g} / \mathrm{mL}$ ). On the other hand, lymphocytes were very sensitive to the salivary components and died in the presence of A. aegypti SGE, even at concentrations as low as $0.1 \mu \mathrm{g} / \mathrm{mL}$. In addition, $A$. aegypti SGE was shown to induce apoptosis in all lymphocyte populations evaluated $\left(\mathrm{CD} 4^{+}\right.$and $\mathrm{CD} 8^{+} \mathrm{T}$ cells, and B cells) through a mechanism involving caspase-3 and caspase-8, but not Bim. By using different approaches to generate memory cells, we were able to verify that these cells are resistant to SGE effects.

Conclusion: Our results show that lymphocytes, and not DCs, are the primary target of A. aegypti salivary components. In the presence of A. aegypti SGE, naïve lymphocyte populations die by apoptosis in a caspase-3-and caspase-8-dependent pathway, while memory cells are selectively more resistant to its effects. The present work contributes to elucidate the activities of $\mathrm{A}$. aegypti salivary molecules on the antigen presenting cell-lymphocyte axis and in the biology of these cells.

Keywords: Dendritic cells, T cells, Aedes aegypti, Saliva, Apoptosis

\footnotetext{
*Correspondence: sanunes@usp.br

'Laboratório de Imunologia Experimental, Departamento de Imunologia,

Instituto de Ciências Biomédicas, Universidade de São Paulo, São Paulo 05508-900, SP, Brazil

${ }^{7}$ Instituto Nacional de Ciência e Tecnologia em Entomologia Molecular,

Conselho Nacional de Desenvolvimento Científico e Tecnológico

(INCT-EM/CNPq), Rio de Janeiro, Brazil

Full list of author information is available at the end of the article
} waiver (http://creativecommons.org/publicdomain/zero/1.0/) applies to the data made available in this article, unless otherwise stated. 


\section{Background}

Mosquitoes are the most important vectors of human pathogens, transmitting a wide number of emerging and re-emerging diseases. In particular, Aedes aegypti mosquitoes are the primary vectors of yellow fever, dengue fever and Chikungunya fever [1-4]. The key interaction element between $A$. aegypti and its vertebrate host is the mosquito saliva and a successful blood meal is achieved by the action of salivary anti-hemostatic and immunomodulatory molecules present in this pharmacological cocktail. The former are responsible for anticoagulant, anti-platelet aggregation and vasodilatory activities $[5,6]$, while the latter is thought to modulate immune functions, which in turn, facilitates pathogen transmission. Indeed, a growing number of recent pieces of evidence have demonstrated that $A$. aegypti salivary components increase viral infection in vitro and in vivo [7-12] and an increased reactivity with mosquito salivary proteins is observed in sera from infected individuals, suggesting a positive correlation between mosquito exposure and risk of infection $[13,14]$.

As a result of their strategic location in the skin, dendritic cells (DCs) interact directly with the mosquito salivary components during and after the blood meal. They are also among the first cells to encounter pathogens transmitted by these vectors and initiate the adaptive immune response against them. Following this initial contact, DCs mature and migrate to the draining lymph nodes, becoming effective stimulators of $\mathrm{T}$ cell responses [15]. Despite DCs essential role in connecting innate and adaptive immune responses, very little is known about the effects of $A$. aegypti salivary components on these cells. A previous study has demonstrated that $A$. aegypti salivary gland extract (SGE) does not affect the viability or IL-12 production by a fetal skin-derived DC line (FSDC) [16]. Therefore, $A$. aegypti SGE has no effect on the basal expression of IFN- $\beta$ by DCs, but it decreases the production of this cytokine in the presence of West Nile Virus infection [9]. In addition to its putative effects on DCs, $A$. aegypti SGE was shown to affect the proliferation of murine lymphocytes in vitro [16-18] and inhibit the production of proinflammatory (GM-CSF and TNF- $\alpha$ ) and Th1 cytokines (IL-2 and IFN- $\gamma$ ), but modest effects were observed on Th2 cytokines levels (IL-4 and IL-5) [16]. On the other hand, it has been shown that the salivary protein SAAG-4 induces $\mathrm{CD}_{4}^{+} \mathrm{T}$ cells to express IL-4 [19]. Accordingly, splenocytes from mice previously exposed to $A$. aegypti bites produced higher levels of IL-4 and IL-10 and decreased IFN- $\gamma$ production [20]. Additionally, recent literature has demonstrated an important functional relationship between coagulation and immunity [21-23] and, in fact, some of the salivary anti-hemostatic molecules described in hematophagous arthropods are also involved in the modulation of host inflammation and immune responses through different mechanisms and pathways [20,24-26].

However, despite the effects described above and the mosquitoes relevance as disease vectors, the immunomodulatory activities of $A$. aegypti saliva on the antigen presenting cell-lymphocyte axis is still very limited. In the current study, we examined the activity of $A$. aegypti SGE on several parameters of DC and lymphocyte biology. Employing murine cells, we demonstrated that modulation of DC maturation, differentiation or function does not seem to be a priority for $A$. aegypti salivary components. Conversely, direct inhibition of naive $\mathrm{T}$ cell proliferation caused by apoptosis is already achieved with low amounts of $A$. aegypti SGE, through a mechanism involving cleavage of pro-caspase- 3 and pro-caspase- 8 , but not the proapoptotic Bcl-2 homolog Bim. Interestingly, memory cells generated by different approaches are selectively resistant to this activity.

\section{Methods \\ Mice}

All the experiments were carried out in accordance with internationally recognized guidelines and approved by the Animal Care of the Institute of Biomedical Sciences of University of São Paulo (CEUA-ICB/USP) and under the protocol number 91/2009. Female BALB/c, C57BL/6, DO11.10 (expressing a TCR transgenic for the sequence of OVA 323-339), $\mathrm{Bim}^{+/-}$and $\mathrm{Bim}^{-/-}$(a proapoptotic member of the Bcl-2 family) mice at 6-16 weeks old were bred and maintained at the Department of Immunology, ICB/USP, Brazil.

\section{Mosquitoes and sandflies}

Male and female A. aegypti and Anopheles aquasalis mosquitoes were reared in an insectary at the Department of Parasitology, ICB/USP, Brazil. Temperature was maintained at $26^{\circ} \mathrm{C}, 80 \%$ humidity and a $12 / 12$-h photoperiod. Larvae were fed on powdered fish food and adult mosquitoes were given continuous access to a $10 \%$ sucrose solution. Salivary glands from Phlebotomus duboscqi sandflies were kindly provided by Dr. Jesus G. Valenzuela, from the Vector Molecular Biology Section, Laboratory of Malaria and Vector Research, National Institutes of Allergy and Infectious Diseases, National Institutes of Health (LMVR/NIAID/NIH, USA).

\section{Salivary gland extracts}

Female mosquitoes aged 4-6 days had their surface sterilized by brief immersion in $70 \%$ ethanol, prior to dissection. The salivary glands were dissected in PBS and transferred to a microtube containing $50 \mu \mathrm{L}$ of cold PBS. Salivary glands of female $P$. duboscqi were collected under the same conditions described above. The tubes containing salivary glands were sonicated to release the 
soluble material and centrifuged at $14,000 \mathrm{~g}$ for 10 minutes to remove particulate material. The resulting supernatant, referred to as SGE, was collected and sterilized by passage through a nitrocellulose membrane filter with $0.2 \mu \mathrm{m}$ pores (Millipore, Carrigtwohill, County Cork, Ireland). Protein concentration was determined by NanoDrop 2000 (Thermo Fisher Scientific, Wilmington, DE, USA) and aliquots were stored at $-80^{\circ} \mathrm{C}$ until use.

\section{Differentiation and maturation of bone marrow-derived DCs (BMDCs)}

BMDCs were employed as a model to study DC biology. Bone marrow cells collected from the femurs of mice were cultured in complete medium (RPMI 1640 medium with $10 \%$ heat-inactivated FBS, $2 \mathrm{mM} \mathrm{L}$-glutamine, $100 \mathrm{U} / \mathrm{mL}$ penicillin, $100 \mu \mathrm{g} / \mathrm{mL}$ streptomycin, $25 \mathrm{mM}$ Hepes, $2.5 \times 10^{5} \mathrm{M} 2$-mercaptoethanol) and $20 \mathrm{ng} / \mathrm{mL}$ of murine GM-CSF to induce DC differentiation $[24,27]$. In order to define if the salivary components would affect the differentiation process, cells were incubated $\left(37^{\circ} \mathrm{C}\right.$ and $\left.5 \% \mathrm{CO}_{2}\right)$ in aliquots of $1 \mathrm{~mL}$ in sterile 24 well plates in the presence of medium only or $A$. aegypti SGE at 2.5, 5, 10, 20 and $40 \mu \mathrm{g} / \mathrm{mL}$ concentrations (6 replicates per group). After 4 days of incubation, non-adherent cells from three replicates of each group were collected by washing with complete medium. On the three remaining replicates, half the volume was removed and replaced by an equal volume of complete medium again containing $40 \mathrm{ng} / \mathrm{mL}$ GM-CSF in the presence or absence of the same concentrations of SGE. At 7 days of incubation, non-adherent cells of the remaining three replicates were collected as described above. In both cases, cells were counted and differentiation of bone marrow cells into DCs in different culture times was assessed by flow cytometry to evaluate the expression of CD11b and CD11c surface markers.

For the maturation assays, BMDCs were obtained and differentiated for 6 days with GM-CSF as described above. Non-adherent cells were collected, resuspended at $10^{6}$ cells $/ \mathrm{mL}$ and distributed into sterile 24 well plates in aliquots of $1 \mathrm{~mL}$ per well. These cells were incubated overnight with medium only or medium containing SGE. Then, cells were stimulated with ultrapure LPS (100 ng/mL - final concentration) for 24 $\mathrm{h}$ to promote their maturation and then labeled with antibodies to MHC class II, CD40, CD80 and CD86 $[24,27]$.

\section{Antigen presentation by DCs}

In order to evaluate the antigen presentation by BMDCs, non-adherent cells were collected at 7 days of incubation and $\mathrm{CD} 11 \mathrm{c}^{+}$cells were purified using magnetic MACS columns (Miltenyi Biotec Inc., Auburn, CA, USA). In brief, BMDC suspensions were incubated with anti-CD11c
MicroBeads (Miltenyi Biotec Inc.) for $15 \mathrm{~min}$ at $4^{\circ} \mathrm{C}$, followed by a PBS wash, and then sorted using MACS columns (MS). Analysis of the sorted cells showed purity of $80-90 \% \mathrm{CD} 11 \mathrm{c}^{+}$cells (data not shown). CD11 ${ }^{+}$cells were preincubated overnight $\left(37^{\circ} \mathrm{C}\right.$ and $\left.5 \% \mathrm{CO}_{2}\right)$ with medium or SGE at various concentrations $(2.5,5,10$, 20 and $40 \mu \mathrm{g} / \mathrm{mL})$. After this period, cells were incubated for $4 \mathrm{~h}$ in the presence of LPS $(100 \mathrm{ng} / \mathrm{mL})$ plus OVA $(100 \mu \mathrm{g} / \mathrm{mL})$. After three washes, $2.5 \times 10^{5}$ cells $/ \mathrm{mL}$ were distributed in aliquots of $100 \mu \mathrm{L}$ per well into a 96-well plate. $\mathrm{CD} 4^{+} \mathrm{T}$ lymphocytes from DO11.10 mice (which express a specific transgenic TCR for the OVA peptide 323-339) were purified using magnetic MACS columns. A suspension containing $10^{6}$ cells $/ \mathrm{mL}$ was prepared and $100 \mu \mathrm{L}$ were added to wells on the culture plate (DC:lymphocyte ratio 1:4) and maintained at $37^{\circ} \mathrm{C}$ and $5 \%$ $\mathrm{CO} 2$ for $72 \mathrm{~h}$.

Similar experiments were performed, but after DC washing, A. aegypti SGE was added again in the culture, followed by addition of $\mathrm{CD}_{4}^{+} \mathrm{T}$ cells from DO11.10 mice (that express a specific transgenic TCR for the OVA peptide 323-339). Cells were stimulated with OVA (100 $\mu \mathrm{g} / \mathrm{mL})$ plus LPS $(100 \mathrm{ng} / \mathrm{mL})$ or Con A $(0.5 \mu \mathrm{g} / \mathrm{mL})$. In the last $24 \mathrm{~h}$ of the culture, $25 \mu \mathrm{L}$ of $0.01 \%$ resazurin were added to all wells. Cell proliferation was evaluated by reading the culture absorbance at 570 and $600 \mathrm{~nm}$, and results are expressed as the difference between those readings as previously described $[24,27,28]$.

\section{Spleen cell proliferation}

Following euthanasia, spleens of $\mathrm{BALB} / \mathrm{c}$ mice were aseptically removed and a cell suspension containing $10^{6}$ cells $/ \mathrm{mL}$ was prepared. Cells were then divided into aliquots of $100 \mu \mathrm{L} /$ well in 96-well plates. Next, $50 \mu \mathrm{l}$ of A. aegypti, An. aquasalis or P. duboscqi at various concentrations were added in the culture and incubated for $30 \mathrm{~min}$. After pre-incubation, $50 \mu \mathrm{L}$ of Con A was added to each well $(0.5 \mu \mathrm{g} / \mathrm{mL}$ - final concentration), and cultures were incubated for $72 \mathrm{~h}$ at $37^{\circ} \mathrm{C}$ and $5 \% \mathrm{CO}_{2}$. Proliferation was evaluated as described $[24,27,28]$.

\section{Apoptosis}

To assess the proportion of viable cells and 'debris', spleen cells were incubated in the presence of $A$. aegypti SGE (final concentration $10 \mu \mathrm{g} / \mathrm{mL}$ ) or medium for $72 \mathrm{~h}$. After this period, the percentage of viable cells was evaluated by flow cytometry using the forward scatter (cell size) and side scatter (granularity) parameters and compared to fresh cells.

For apoptosis quantification, spleen cells were incubated in the presence of $A$. aegypti SGE or medium for 4, 8, 24 and $72 \mathrm{~h}$. Cells were labeled with lymphocyte markers (CD4, CD8 and CD19) for subpopulation analysis. Cells 
were then washed twice with PBS and resuspended with $500 \mu \mathrm{L}$ of Annexin-binding buffer ( $0.1 \mathrm{M}$ Hepes, 1.4 $\mathrm{M} \mathrm{NaCl}, 25 \mathrm{mM} \mathrm{CaCl} 2$ ). Subsequently, $5 \mu \mathrm{L}$ of Annexin V-FITC was added to the cell suspension, which was then incubated in the dark for $10 \mathrm{~min}$ at room temperature. Cells were evaluated by flow cytometry and apoptosis was measured by the percentage of Annexin $\mathrm{V}^{+}$cells.

For Western blot analysis, spleen cells from BALB/c mice were prepared as described previously. Cell suspensions containing $20 \times 10^{6} \mathrm{cells} / \mathrm{ml}$ were incubated with medium only or in the presence of Ae. aegypti SGE (final concentration: $10 \mu \mathrm{g} / \mathrm{mL}$ ) and stimulated with Con A (final concentration $0.5 \mu \mathrm{g} / \mathrm{mL}$ ) for $4 \mathrm{~h}$ at $37^{\circ} \mathrm{C}$ and $5 \% \mathrm{CO}_{2}$. Cells were then collected, washed twice with PBS and lysed with $100 \mu \mathrm{L}$ of RIPA buffer (150 mM NaCl, 1\% NP40, 0.1\% SDS, $50 \mathrm{mM}$ Tris; $\mathrm{pH}$ 8.0) supplemented with $1 \%$ of protease inhibitor (Sigma- Aldrich, St. Louis, MO, USA). The lysate supernatant was collected after 10 minutes incubation, centrifuged at $14000 \mathrm{~g}$ for 5 minutes and the protein concentration was determined using BCA Protein Assay Kit according to the manufacturer's instructions (Thermo Fisher Scientific, Rockford, IL, USA).

The equivalent of $30 \mu \mathrm{g}$ protein from each sample were diluted $\mathrm{v} / \mathrm{v}$ in Laemmli buffer (2\% SDS, $10 \%$ glycerol, $1 \% \beta$-mercaptoethanol, $0.02 \%$ bromophenol blue, $0.4 \mathrm{M}$ Tris), heated to $100^{\circ} \mathrm{C}$ for 5 minutes and separated by electrophoresis in a $12 \%$ Sodium Dodecyl Sulfate (SDS) polyacrylamide gel under a constant current of $20 \mathrm{~mA}$. The separated proteins were transferred to a nitrocellulose membrane which was then blocked for 1 hour with 5\% FBS diluted in Tris buffer containing 0.1\% Tween -20 (TBST). Membranes were washed 3 times with TBST (10 minutes per wash) and incubated overnight at $44^{\circ} \mathrm{C}$ with the following rabbit monoclonal antibodies: antipro-caspase-3 (1:500) and anti-pro-caspase-8 $(1: 1,000)$, both from Cell Signaling Technology, Inc. (Danvers, MA, USA). After further washing, the membranes were incubated for 1 hour at room temperature with antirabbit secondary antibodies $(1: 2,000)$ conjugated with horseradish peroxidase for detection (Dako, Glostrup, Denmark). Immunoreactive bands were stained using the chemiluminescent ECL Detection Kit (Thermo Fisher Scientific) and visualized in a photodocumentation system. The membranes were then washed and incubated overnight with anti $\beta$-actin $(1: 10,000)$, followed by another washing and subsequent incubation with a antimouse secondary antibody $(1: 60,000)$. The density of the bands was analyzed using Image $J$ software (available free at http://rsb.info.nih.gov/nih-image). The values were normalized by the total of $\beta$-actin present in each sample and expressed as arbitrary units.

\section{Mice sensitization by mosquito bite}

Male and female mosquitoes A. aegypti and An. aquasalis were kept in plastic containers of about $12 \mathrm{~cm}$ diameter covered with a fine mesh screen. Mice were anesthetized and placed on the screen for $20-30 \mathrm{~min}$ so that female mosquitoes had direct contact with the animal's skin for enough time to complete the blood meal, as previously standardized (data not published). This whole procedure was performed four times at 15 day intervals, using approximately 50 female mosquitoes per mice and the proportion of mosquitoes fed at each sensitization was typically $\geq 80 \%$. Mice from the control group were also anesthetized, but had no contact with mosquitoes. Fifteen days after the last sensitization, proliferation was performed as described above.

\section{Adoptive transfer and mice immunization}

Spleen cells from DO11.10 mice were prepared in complete medium and incubated at $37^{\circ} \mathrm{C}$ and $5 \% \mathrm{CO}_{2}$ for $2 \mathrm{~h}$ in Petri dishes. Non-adherent cells were collected and the cell suspension was prepared in PBS containing 1\% fetal bovine serum. These cells were inoculated i.v. to BALB/c mice in a volume of $200 \mu \mathrm{L}$ containing $3 \times 10^{6}$ cells. After $24 \mathrm{~h}$, these mice were immunized subcutaneously at two sites of the dorsal region with $100 \mu \mathrm{L}$ of an emulsion containing OVA and complete Freund's adjuvant v/v (40 $\mu \mathrm{g}$ of OVA per animal). After 7 days, spleens cells of control and immunized animals were collected and cell suspensions $\left(10^{6}\right.$ cells $\left./ \mathrm{mL}\right)$ prepared. In vitro re-stimulation assays were performed with cells pre-incubated with medium alone or SGE for 30 minutes followed by stimulation with OVA $(100 \mu \mathrm{g} / \mathrm{mL})$ or Con A $(0.5 \mu \mathrm{g} /$ $\mathrm{mL}$ ). The proliferation of these cells was assessed as described above. Naïve and memory phenotyping was performed in $\mathrm{CD} 4^{+} \mathrm{T}$ cells by flow cytometry as follows: CD62 $\mathrm{L}^{\mathrm{HIGH}} / \mathrm{CD} 44^{\mathrm{LOW}}$ (naïve cells), CD62 $\mathrm{L}^{\mathrm{HIGH}}$ / $\mathrm{CD} 44^{\mathrm{HIGH}}\left(\mathrm{T}_{\mathrm{CM}}\right.$ cells), and $\mathrm{CD} 62 \mathrm{~L}^{\mathrm{LOW}} / \mathrm{CD} 44^{\mathrm{HIGH}}$ ( $\mathrm{T}_{\mathrm{EM}}$ cells).

\section{Flow cytometry}

Cells were prepared for flow cytometry as previously described [24,27]. Fluorochrome-conjugated monoclonal antibodies against the following molecules were employed: CD4-APC, CD19-PE, CD11b-FITC, CD11c-PE, CD40FITC, CD80-PerCP-Cy5.5, CD86-PE-Cy7 (BD Biosciences, San Jose, CA); CD8-PerCP, Annexin-FITC, I-A/I-E-APC, CD44-Pacific Blue, CD62L-PE (Biolegend, San Diego, CA, USA). Cells were acquired in a FACSCanto II (BD Biosciences) and analysis was performed using FlowJo software, version 7.5.5 (Tree Star, Ashland, OR, USA).

\section{Statistical analysis}

Statistical analysis of differences between means of experimental groups was performed using Student's $t$ test 
(for two groups comparisons) or analysis of variance (ANOVA) followed by Tukey as a post-test (for three or more groups). A value of $p \leq 0.05$ was considered statistically significant.

\section{Results}

\section{A. aegypti SGE does not interfere with dendritic cell} differentiation or maturation

BMDCs from BALB/c mice were cultured with GM-CSF in the presence of different concentrations of $A$. aegypti saliva and their differentiation was evaluated by flow cytometry through the percentage of $\mathrm{CD} 11 \mathrm{c}^{+} / \mathrm{CD} 11 \mathrm{~b}^{+}$ cells. Figure 1 shows that $A$. aegypti SGE did not affect the differentiation of BMDCs at 4 or 7 days of culture (Figure 1A), as comparable percentages of $\mathrm{CD} 11 \mathrm{c}^{+} / \mathrm{CD} 11 \mathrm{~b}^{+}$ cells were observed in all groups on both days (Figures $1 \mathrm{~B}$ and $1 \mathrm{C}$ ). These sets of experiments were also performed with BMDC from C57BL/6 mice and similar results were achieved (data not shown).

To assess whether $A$. aegypti saliva has an effect on DCs maturation, we analyzed the expression pattern of MHC class II and costimulatory molecules on DCs after incubation with LPS in the presence of SGE. As expected, immature DCs present variable levels of extracellular MHC class II expression (low, mid and high) and, upon LPS stimulation, the majority of these cells shift to $\mathrm{MHC}$ class $\mathrm{II}^{\mathrm{HIGH}}$, confirming DC maturation.
However, the presence of SGE did not alter the expression of MHC class II either in immature or mature DCs (Figure 2A). No differences were found in the sample's mean fluorescent intensity (MFI), indicating similar levels of expression of this marker (data not shown). The expression of CD40 was also upregulated in $\mathrm{CD}_{11 \mathrm{c}^{+}}$cells upon LPS stimulation when compared to control cells (incubated with medium only), but again, the presence of SGE in the culture did not affect CD40 expression (Figure 2B). The same was observed with CD80 and CD86 expression (data not shown).

\section{A. aegypti SGE inhibits T cell proliferation in a DC-independent fashion}

In order to investigate the effect of $A$. aegypti SGE on antigen presentation by DCs, purified $\mathrm{CD}_{11 \mathrm{c}^{+}}$cells were incubated with SGE, pulsed with OVA plus LPS and after repeated washings to remove SGE, OVA and LPS residues, these cells were coincubated with $\mathrm{CD} 4^{+} \mathrm{T}$ lymphocytes from DO11.10 mice and the proliferation was evaluated $[24,27,28]$. OVA-pulsed DCs stimulated $\mathrm{CD}^{+}{ }^{+} \mathrm{T}$ cell proliferation when compared to control (DCs incubated with medium alone). Nonetheless, when DCs were preincubated with $A$. aegypti SGE, the specific proliferation of $\mathrm{CD}^{+}{ }^{+} \mathrm{T}$ cells was not affected (Figure $3 \mathrm{~A}$ ).

In another set of experiments, SGE was added again to the culture after DC washing, followed by coincubation
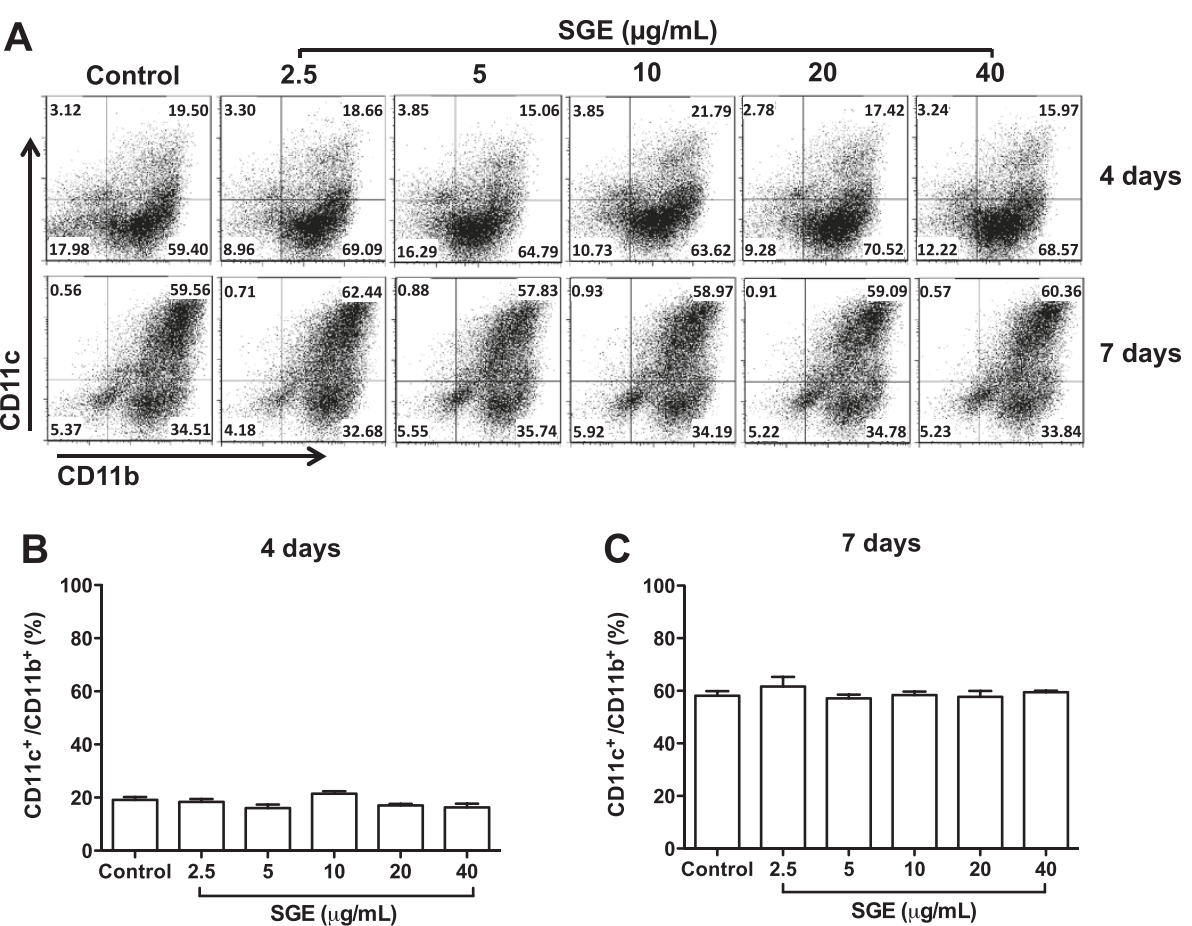

Figure $1 \mathrm{~A}$. aegypti SGE does not interfere with DC differentiation. BMDC from BALB/c mice were cultured with GM-CSF in the presence or absence of A. aegypti SGE (final concentration: 2.5, 5, 10, 20 and $40 \mu \mathrm{g} / \mathrm{mL}$ ) for 4 and 7 days and analyzed by flow cytometry. Dot plots (A) and the mean of relative percentage of $\mathrm{CD}_{11} \mathrm{~b}^{+} / \mathrm{CD} 11 \mathrm{c}^{+}$cells present in culture at 4 days (B) and 7 days (C) are presented. 


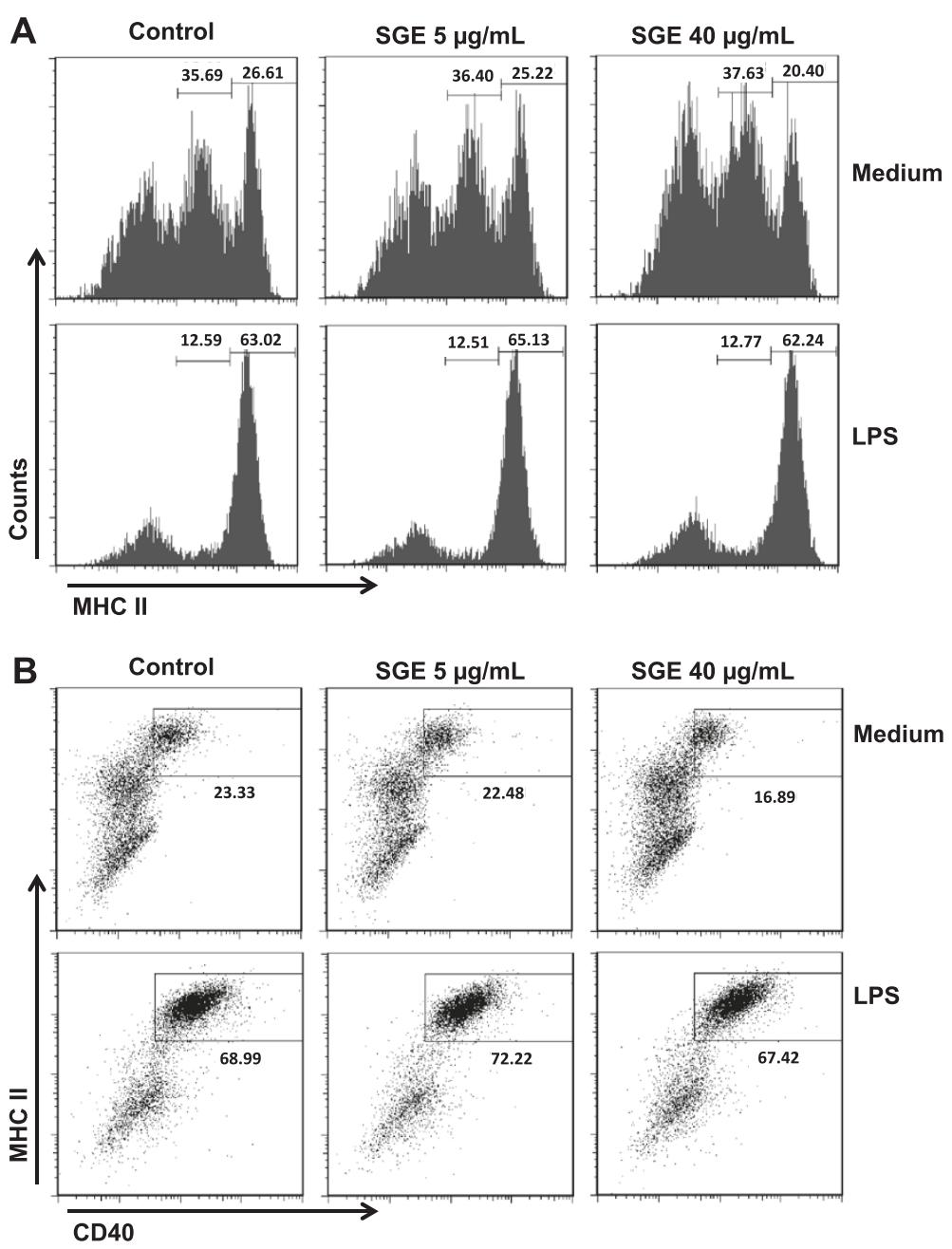

Figure 2 DC maturation is not affected by $A$. aegypti SGE. DCs were differentiated with GM-CSF for 6 days, preincubated overnight in the presence or absence of $A$. aegypti SGE (final concentration: 5 and $40 \mu \mathrm{g} / \mathrm{mL}$ ) and stimulated or not with LPS (100 $\mathrm{ng} / \mathrm{mL}$ ), as indicated. Expression of MHC class II (A) and CD40 (B) was evaluated in CD11 $\mathrm{C}^{+}$cells by flow cytometry.

with T cells from DO11.10 mice. Under these conditions, antigen-specific $\mathrm{CD} 4^{+} \mathrm{T}$ cell proliferation was completely abolished (Figure 3B). The same approach was performed, but stimulating the cultures with Con A, a polyclonal activator of $\mathrm{T}$ cells. Figure $3 \mathrm{C}$ shows that if SGE is maintained in the culture, polyclonal activation of $\mathrm{T}$ cells is also completely inhibited. These results were confirmed through CFSE staining (Additional file 1). Together, these data show that $A$. aegypti salivary components affect $\mathrm{T}$ lymphocytes in a DC-independent manner.

Next, we evaluated the potency of this inhibitory activity by incubating spleen cells with increasing concentrations of SGE followed by Con A stimulation. Figure 3D shows that SGE induced a concentration-dependent decrease of $\mathrm{T}$ cell proliferation, reaching maximal inhibition at $10 \mu \mathrm{g} / \mathrm{mL}$. Of note, similar inhibitory activity was found for spleen cells from C57BL/6 mice (data not shown). We have also tested if salivary components of hematophagous species other than $A$. aegypti possessed such inhibitory activity. Interestingly, neither SGE from An. aquasalis mosquitoes (Figure 3E) nor from $P$. duboscqi sandflies (Figure 3F) were able to affect lymphocyte proliferation under the same conditions.

\section{A. aegypti SGE induces caspase- 3 and caspase- 8 dependent lymphocyte apoptosis}

As expected, when a spleen cell culture stimulated with Con A for 3 days is analyzed by flow cytometry, most lymphocytes appear larger in "size" and with more granularity compared to fresh cultures, indicating their activation (Additional file 2). The presence of $A$. aegypti SGE in this culture drastically changes cell phenotype, as the amount of "viable cells" is inversely proportional to SGE concentration, suggesting cell death (Additional file 2). In order to investigate the mechanism by which cells would be dying in the presence of SGE, we evaluated several 

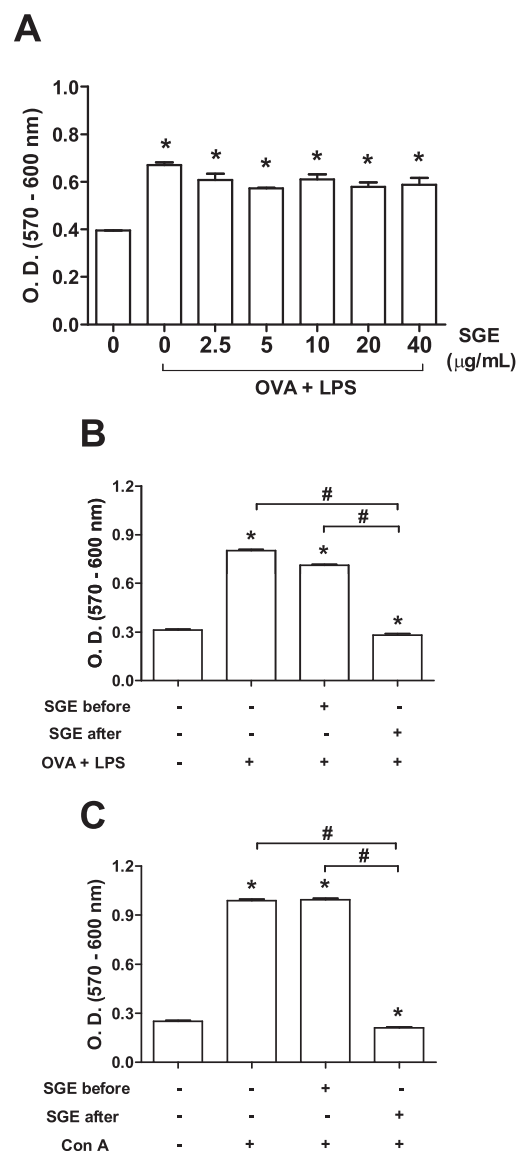

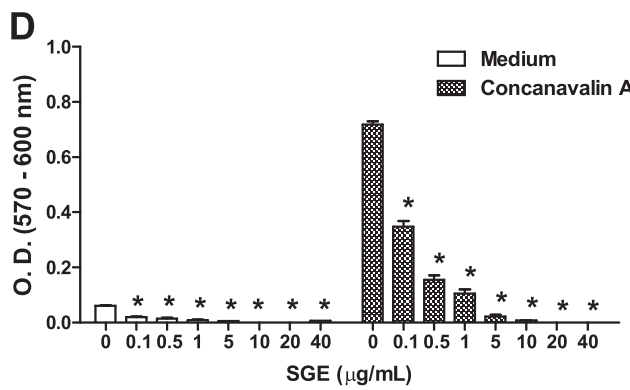

E
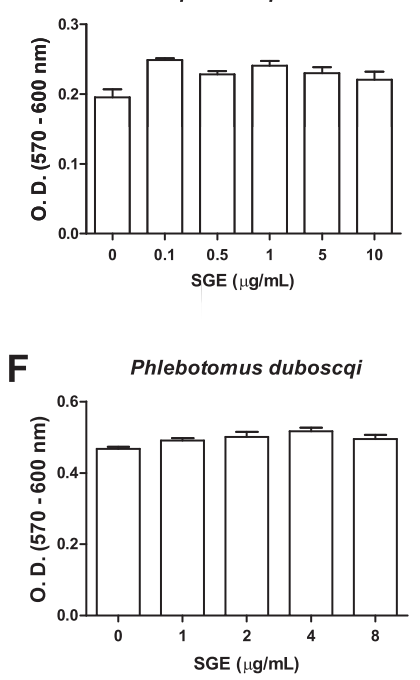

Figure 3 A. aegypti SGE inhibits T cell proliferation in a DC-independent fashion. DCs were pre-incubated overnight in the presence or absence of A. aegypti SGE (final concentrations indicated) and stimulated for $4 \mathrm{~h}$ with OVA (100 $\mu \mathrm{g} / \mathrm{mL}) \mathrm{plus} \mathrm{LPS} \mathrm{(100} \mathrm{ng/mL).} \mathrm{After} 3$ washings, DCs were co-incubated with CD4 ${ }^{+}$cells from D011.10 mice for $72 \mathrm{~h}$ (A and B). Similar DC/CD4 ${ }^{+}$cultures were also stimulated by Con A for 72 h (C). In some groups, SGE was added again after washing the cells (B and C). Concentration-response effect of A. aegypti SGE on Con A-induced spleen cells proliferation (D). Absence of effect of An. aquasalis (E) and P. dubosqi SGE (F) on Con A-induced spleen cells proliferation. " $p<0.05$ versus "C" (control); $p<0.05$ versus stimulated with OVA + LPS or Con A.

apoptosis parameters. Figure 4A shows that annexin V staining is increased in total spleen cells stimulated by Con $\mathrm{A}$ in the presence of $A$. aegypti SGE when compared to cells stimulated with Con A only. A similar phenotype is observed in $\mathrm{CD}^{+}$and $\mathrm{CD}^{+} \mathrm{T}$ cells population as well as in $\mathrm{CD}_{19^{+}} \mathrm{B}$ cells (Figure 4A).

In order to further characterize the molecular pathway (s) involved in the apoptosis induced by A. aegypti salivary components, we evaluated the expression of pro-caspase- 3 and pro-caspase- 8 in total spleen cell lysates. As observed in Figure $4 \mathrm{~B}$, levels of both pro-caspases are reduced in cells incubated with Con A plus SGE when compared to cells stimulated with Con A alone.

\section{Naïve and memory $T$ cells are differentially affected by}

\section{A. aegypti SGE}

Memory cells are known to be more resistant to apoptosis than naïve $\mathrm{T}$ cells [29]. Because Bim, a proapoptotic member of the Bcl-2 family, is involved in $\mathrm{T}$ cell homeostasis and memory $\mathrm{T}$ cells are resistant to Biminduced apoptosis [30], we tested whether spleen cells from Bim knockout mice $\left(\mathrm{Bim}^{-/-}\right)$were as sensitive as their heterozygous counterparts $\left(\mathrm{Bim}^{+/}\right)$to the inhibitory effects of $A$. aegypti SGE. Figure $4 \mathrm{C}$ shows that spleen cells from either $\mathrm{Bim}^{-/-}$or $\mathrm{Bim}^{+/-}$are equally affected by SGE, suggesting that the intrinsic apoptosis pathway does not play a role in SGE-induced apoptosis.

To further investigate the observed phenomenon, we generated memory cells by natural sensitization of mice to $A$. aegypti bites and evaluated the proliferation of spleen cells from these animals. As previously demonstrated (Figure 3D), A. aegypti SGE inhibits both basal cell metabolism and Con A-induced proliferation of spleen cells (Figure 5A). Contrarily, cells from mice sensitized with $A$. aegypti bites display antigen-specific proliferation in the presence of SGE (Figure 5B). Interestingly, when stimulated by Con A in the presence of SGE, proliferation 

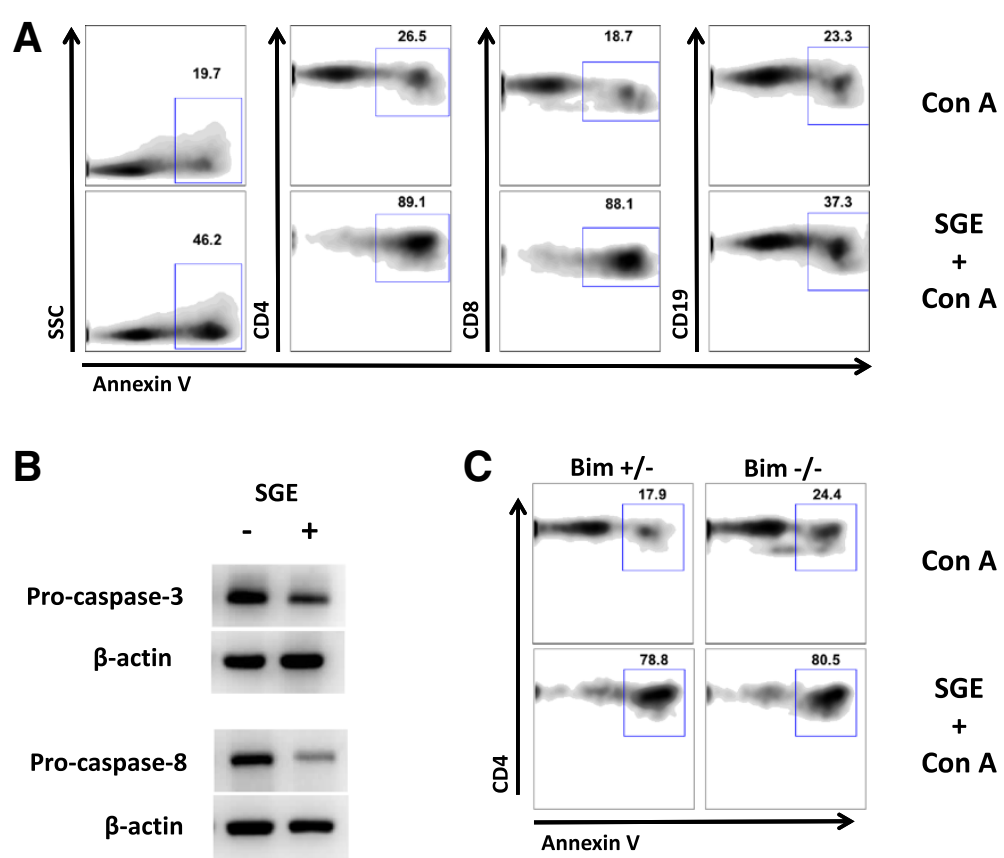

Con A

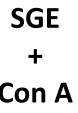

Figure 4 A. aegypti SGE induces lymphocyte apoptosis and cleavage of pro-caspase 3 and pro-caspase-8. Total spleen cells were incubated with Con A in medium only or in presence of A. aegypti SGE for $4 \mathrm{~h}$. Annexin V staining was evaluated by flow cytometry in total cells, $\mathrm{CD}^{+}, \mathrm{CD}^{+}$and $\mathrm{CD} 19^{+}$cells from WT mice (A) or $\mathrm{CD}^{+} \mathrm{T}$ cells from Bim ${ }^{+-}$and Bim ${ }^{-1-}$ mice (C). Lysates of similar cell cultures were blotted against a monoclonal antibody against pro-caspase-3 and pro-caspase-8 (B).

of these cells was only partially inhibited, and the proportion of surviving cells corresponded to the amount of antigen specific proliferating cells (Figure $5 \mathrm{~B}$ - dotted line). The secretion of neutralizing antibodies against salivary components by B lymphocytes present in the culture could not explain the lack of inhibition observed, since culture supernatants from spleen cells of sensitized mice, used as conditioned media, did not block (even partially) the effect of SGE on T cells from non-sensitized mice (Additional file 3).

We also investigated the effects of $A$. aegypti SGE on spleen cell proliferation of mice sensitized with bites of An. aquasalis, a species belonging to a different mosquito subfamily. Spleen cells from An. aquasalis-sensitized mice proliferate in the presence of SGE from this species, but not in the presence of $A$. aegypti SGE, indicating antigen-specific stimulation (Figure $5 \mathrm{C}$ ). When these cells are incubated with both SGE (from $A$. aegypti and $A n$. aquasalis), the proliferative response persists, confirming the lack of $A$. aegypti SGE activity on memory cells generated against An. aquasalis salivary components (Figure 5C). Additionally, when spleen cells from $A n$. aquasalis-sensitized mice are stimulated with Con A or An. aquasalis SGE, a significant proliferation is observed, possibly from both naïve and memory cells. Stimulation with Con $\mathrm{A}$ in the presence of $A$. aegypti SGE only, or together with $A n$. aquasalis SGE, induces a partial inhibition of the proliferative response. The partial blockage of proliferation observed suggests again that while the memory cell population survives and continues to proliferate, the naive population dies in the culture (Figure $5 \mathrm{C}$ ). This finding implies that $A$. aegypti SGE does not affect the memory cells generated against salivary components of other mosquito species (e.g. mice sensitized with An. aquasalis bites).

In order to further test our hypothesis, we generated memory cells against OVA, an antigen not related to mosquito salivary molecules. Recipient BALB/c mice were adoptively transferred with cells from DO11.10 mice and immunized with OVA to induce expansion of the donor cells and allow the generation of memory cells. One week later, spleen cells from recipient animals were preincubated in vitro with $A$. aegypti SGE and stimulated with Con A or OVA to assess the polyclonal and antigen-specific proliferation, respectively. Figure 5D shows that basal metabolism of cells incubated with medium or OVA, as well as Con A-induced proliferation from naïve mice are all significantly inhibited by $A$. aegypti SGE, as expected. On the contrary, spleen cells from mice adoptively transferred with DO11.10 cells and immunized with OVA had the Con A-induced proliferation only partially inhibited and, more important, antigen-specific proliferation was not affected at all (Figure 5E).

Finally, we evaluated the naïve and activated/memory markers in $\mathrm{CD}^{+}{ }^{+} \mathrm{T}$ cell populations in medium only or 

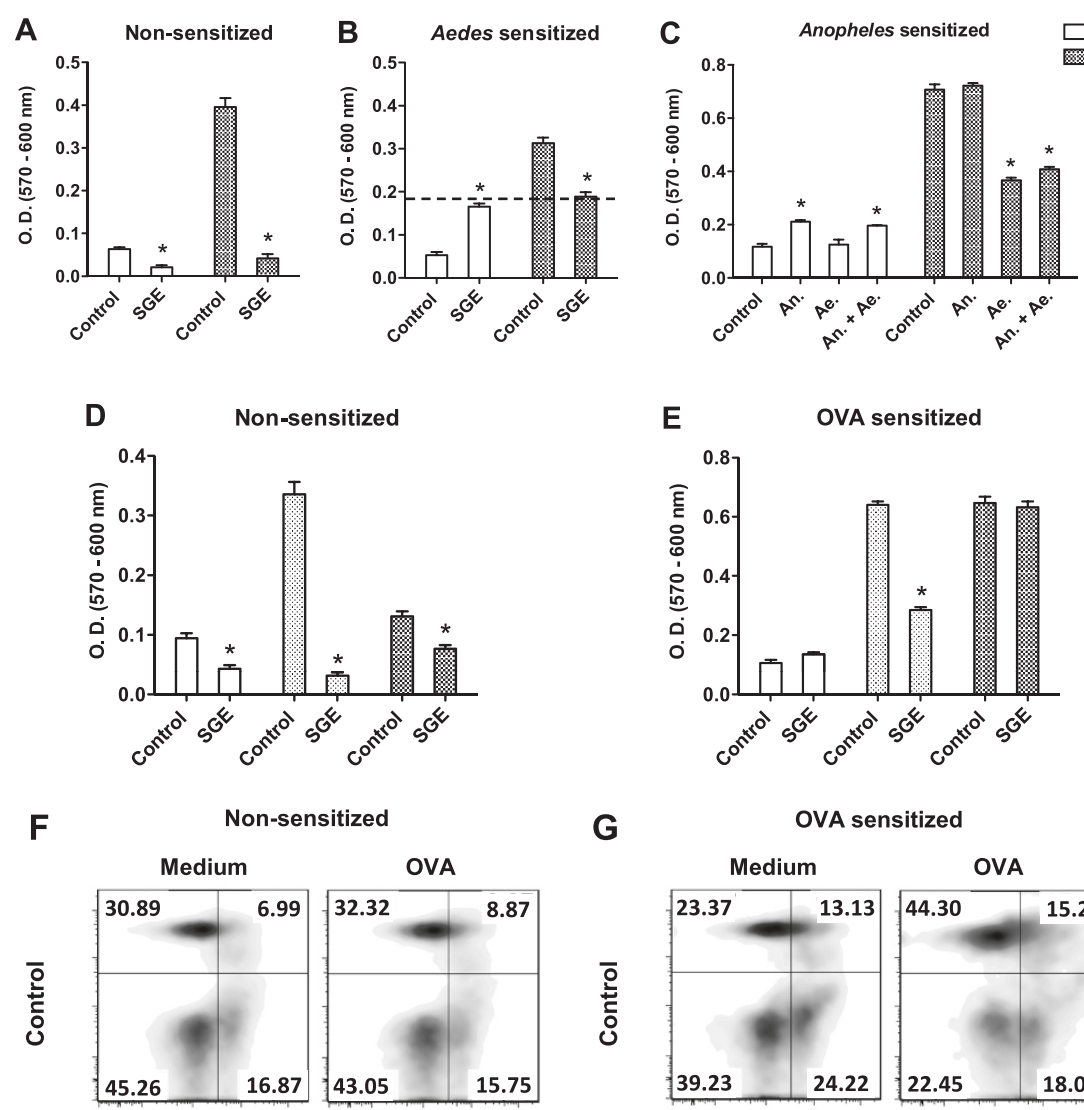

\section{G}
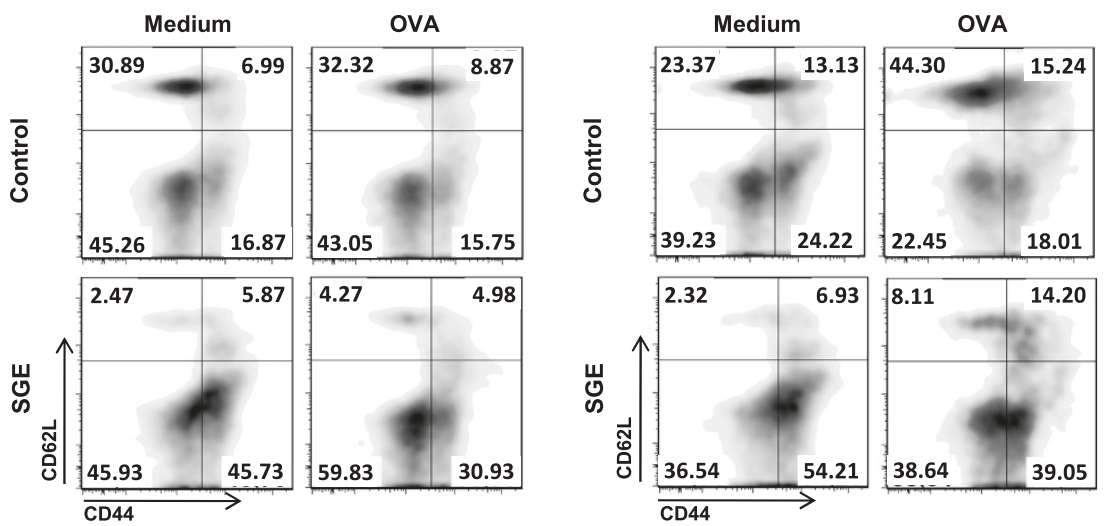

Figure 5 Memory cells are resistant to A. aegypti SGE effects. Spleen cells from non-sensitized (A) and A. aegypti-sensitized BALB/c mice (B) were incubated with medium only or with A. aegypti SGE $(5 \mu \mathrm{g} / \mathrm{mL})$ and/or stimulated with Con A $(0.5 \mu \mathrm{g} / \mathrm{mL})$ for $72 \mathrm{~h}$. Cells from An. aquasalis-sensitized mice were cultured with medium only or in the presence of $5 \mu \mathrm{g} / \mathrm{mL}$ An. aquasalis SGE (An.) and/or $5 \mu \mathrm{g} / \mathrm{mL} \mathrm{A.} \mathrm{aegypti}$ SGE (Ae.) and then stimulated with $0.5 \mu \mathrm{g} / \mathrm{mL}$ Con A (C). Non-adherent D011.10 spleen cells were adoptively transferred to BALB/c mice and after 7 days, recipient mice were sensitized with OVA and complete Freund's adjuvant (40 $\mu \mathrm{g} / \mathrm{animal})$. Spleen cells from non-sensitized (D) and sensitized mice (E) were obtained after 7 days and cultured in the presence of medium or A. aegypti SGE and stimulated with Con A (0.5 $\mu \mathrm{g} / \mathrm{mL})$

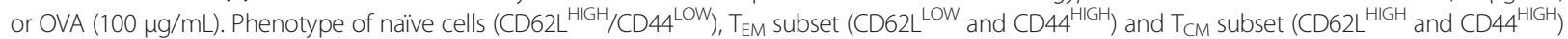
from non-sensitized (F) or sensitized mice (G) were evaluated by flow cytometry after $72 \mathrm{~h}$ cultured in presence of medium or A. aegypti SGE and stimulated with Con A or OVA. $p<0.05$ versus respective control group.

under OVA stimulation. CD62 $\mathrm{L}^{\mathrm{HIGH}} / \mathrm{CD} 44^{\mathrm{LOW}}$ were considered naïve $\mathrm{T}$ cells while memory cells were divided into two subsets: effector memory $\mathrm{T}$ cells $\left(\mathrm{T}_{\mathrm{EM}}\right)$ that express $\mathrm{CD} 62 \mathrm{~L}^{\mathrm{LOW}}$ and $\mathrm{CD} 44^{\mathrm{HIGH}}$; and central memory cells $\left(\mathrm{T}_{\mathrm{CM}}\right)$ which express $\mathrm{CD} 62 \mathrm{~L}^{\mathrm{HIGH}}$ and $\mathrm{CD} 44^{\mathrm{HIGH}}$ [31-35]. Figure 5 shows that both, $\mathrm{T}_{\mathrm{EM}}$ and $\mathrm{T}_{\mathrm{CM}}$ subsets, were increased in OVA-sensitized mice when compared to non-sensitized mice (upper left panels - Figures $5 \mathrm{~F}$ and 5G). The addition of $A$. aegypti SGE to the cultures, affected naïve cell populations in both groups (lower left panels). The presence of OVA expanded both memory subsets in OVA-sensitized spleen cell cultures when compared to cultures of spleens from non-sensitized mice as expected (upper right panels - Figures $5 \mathrm{~F}$ and 5G). Remarkably, coincubation with OVA plus SGE strongly affected $\mathrm{CD} 62 \mathrm{~L}^{\mathrm{HIGH}} / \mathrm{CD} 44^{\mathrm{LOW}}$ naïve $\mathrm{T}$ cell population in both groups, while memory subsets were preserved or even increased, especially in the cultures from OVA-sensitized mice (lower right panels - Figures 5F and 5G). All these findings were concentration-dependent, as observed in Additional file 4. Taken together, these data show that naïve $\mathrm{CD} 4^{+} \mathrm{T}$ cells are susceptible, while memory $\mathrm{T}$ cells are selectively more resistant, to the apoptotic effect of $A$. aegypti SGE. 


\section{Discussion}

The blood-feeding behaviour is present in several orders of insects that have acquired the genetic and morphofunctional resources to suck, digest and use the blood of their vertebrate hosts [36]. Over millions of years of evolution, hematophagous mosquitoes have developed a complex pharmacological cocktail in their saliva, which clearly modulates host vascular and immune systems. Nevertheless, our knowledge of these processes is incomplete. The present study aimed to investigate the putative immunomodulatory effects of salivary components of $A$. aegypti mosquito vector on the differentiation, maturation and function of DCs and on the proliferation of T lymphocytes.

Pioneering work has shown that saliva of Rhipicephalus sanguineus, the "brown dog tick", is able to inhibit differentiation and maturation of murine DCs [37]. In addition, Sá-Nunes et al. (2007) were the first to isolate and characterize prostaglandin $\mathrm{E}_{2}\left(\mathrm{PGE}_{2}\right)$ as the major $\mathrm{DC}$ modulator in saliva of Ixodes scapularis ticks, the Lyme disease vector [24]. Recently, $\mathrm{PGE}_{2}$ found in the saliva of Dermacentor variabilis ticks was also shown to regulate macrophage migration and cytokine production by these cells [38]. In addition, the presence of $\mathrm{PGE}_{2}$ in $R$. sanguineus saliva was also demonstrated, although in smaller amounts than I. scapularis [39]. However, the capacity of $R$. sanguineus saliva to modulate DCs is complemented by the presence of adenosine [39]. Additional studies have demonstrated the immunoregulatory and anti-inflammatory activity of crude tick saliva [40,41] and other proteinaceous components capable of modulating the function of DCs, such as Salp15 [42] and sialostatin L [27], both identified in the I. scapularis saliva. Although these previous pieces of evidence show a clear effect of the tick saliva on DCs, very little is known about the modulation of these cells by saliva of blood feeding insects. Costa et al. (2004) demonstrated that SGE of Lutzomyia longipalpis sandflies, one of the leishmaniasis vectors in the new world, affects cytokine production and costimulatory activity of human DCs [43]. Some years later, it was shown that SGE of $P$. duboscqi and $P$. papatasi sandfly species induced the production of PGE ${ }_{2}$ and IL-10 by DCs [44]. The observed effects of P. papatasi SGE on DCs was due to the presence of adenosine and adenosine monophosphate ( $5^{\prime}$ AMP) and this seems to be, at least partially, the mechanism by which the SGE of this species was able to decrease the arthritis symptoms in an autoimmune model induced by collagen [25].

DCs comprise distinct developmental and functional subsets present in lymphoid and non-lymphoid tissues and are involved in the activation of adaptive immune responses, but also in tolerance to self-antigens [45]. However, their frequencies in the tissues limit their experimental use. For example, Langerhans cells (the DC population from the epidermal layer of the skin) account for $3-5 \%$ of epidermal cells [46]. Accordingly, classical DCs such as those found in the dermis, represent 1-5\% of total cells from peripheral tissues [45]. In addition, the increasing number of DC phenotypes described and isolation protocols employing enzymatic digestion which temporarily destroy surface markers, are other factors to consider [45]. Thus, although the BMDCs preparations employed in the present work do not precisely represent the population of epidermal and dermal DCs that possibly interact with mosquito saliva, the use of these cells to investigate the biological effects of salivary preparations or their purified components is accepted by most studies in the field $[9,24,27,37,44,47]$. To our surprise, A. aegypti SGE had no effect on DCs differentiation (Figure 1), maturation (Figure 2) and antigen presentation to $\mathrm{T}$ lymphocytes (Figure 3A). Corroborating with this data, it has been demonstrated that $A$. aegypti SGE did not affect the viability of a murine DC line [16]. These results contrast greatly with data described in other species of arthropod vectors and, in the specific case of $A$. aegypti, our results are original in demonstrating that direct modulation of DCs by salivary components does not seem to be a property of the saliva from this mosquito species.

Interestingly, addition of $A$. aegypti SGE to cultures of $\mathrm{CD} 11 \mathrm{c}^{+}$cells after washing caused a significant inhibition in antigen specific (Figure 3B) and polyclonal (Figure 3C) proliferation of $\mathrm{CD}^{+} \mathrm{T}$ lymphocytes. This data confirms that SGE acts directly on T lymphocytes and not on antigen-presenting cells, and corroborates with findings in the literature showing the negative modulation of lymphocyte function by $A$. aegypti salivary components [16-18]. We also observed that SGE of other insect species (namely An. aquasalis, and P. duboscqi) had no inhibitory effect on $\mathrm{T}$ cell proliferation (Figures $3 \mathrm{E}$ and $3 \mathrm{~F}$ ). Wanasen et al. [18] also observed the absence of effects on T cell proliferation employing SGE of Culex quinquefasciatus, which belongs to the same mosquito subfamily. To our knowledge, such inhibitory activity was only found in the SGE of another nematoceran species, the black fly Simulium vittatum [48].

We have also explored the mechanisms by which the A. aegypti SGE inhibits lymphocyte proliferation. Our results show that this inhibition occurs due to induction of apoptosis in spleen cells, more specifically on $\mathrm{T}\left(\mathrm{CD} 4^{+}\right.$ and $\left.\mathrm{CD}^{+}\right)$and $\mathrm{B}\left(\mathrm{CD} 19^{+}\right)$cells (Figure $\left.4 \mathrm{~A}\right)$. The specificity of such biological activity is evidenced by DC assays, since differentiation, maturation and function were not affected, even when these cells were incubated with $40 \mu \mathrm{g} /$ mL SGE, a 4-fold increase in the maximum concentration effect on the proliferative response. As previously reported, decreased $\mathrm{T}$ cell proliferation induced by $A$. aegypti SGE 
was due to diminished cell viability, as evaluated by PI and 7-AAD expression, both DNA markers [16,18]. It is important to emphasize that these markers are not specific for apoptotic cell death. Our findings unveiled that $A$. aegypti SGE induces apoptosis in T and B lymphocytes as assessed by exposure of phosphatidylserine (labeled with annexin V) at the surface of these cells (Figure 4A). Furthermore, our results suggest that caspase-3 (an executor caspase) and caspase-8 (an initiator caspase), but not Bim (a proapoptotic member of the intrinsic pathway), are likely to be involved in the apoptosis signaling induced by $A$. aegypti SGE (Figures 4B and $4 \mathrm{C}$ ). As $\mathrm{T}$ and $\mathrm{B}$ cells are components of the adaptive immune response, it is reasonable to imagine that their effector functions (antibody secretion, cytotoxic granules or helper activities) are somehow deleterious to the mosquito life cycle. In fact, a classical study has demonstrated a decrease in the fecundity of mosquitoes fed on rabbits or guinea pigs immunized with a $A$. aegypti whole body homogenate [49].

Memory $\mathrm{T}$ cells are known to be more resistant to apoptosis than naïve $\mathrm{T}$ cells due to the increased expression of anti-apoptotic proteins [29]. Because cells from $\mathrm{Bim}^{-1-}$ mice are as susceptible to apoptosis as cells from $\mathrm{Bim}^{+/-}$mice (Figure 4C), and it is well known that this differential resistance is considerably dependent on the neutralization of Bim-mediated apoptosis by increased levels of Bcl-2 [29,30], we investigated whether the $A$. aegypti salivary components would also have an effect on memory cells. Initially, mice were sensitized with $A$. aegypti bites and the effect of SGE on proliferative response of spleen cells from these animals was evaluated. Unlike naïve spleen cells (Figure 5A), those derived from sensitized animals proliferate in the presence of SGE (Figure 5B). In addition, when these cells were stimulated with Con A, only partial inhibition was achieved, suggesting that the memory cells present in the culture continue to proliferate even in the presence of SGE inhibitory factor(s). We rule out the role of neutralizing antibodies produced by B lymphocytes present in the culture on this effect, since spleen cell supernatants from sensitized mice, used as conditioned media, did not block the effect of SGE on T cells from non-sensitized mice (Additional file 3). Other explanations/mechanisms cannot be ruled out, such as peripheral tolerance and development of regulatory $\mathrm{T}$ cells, and will be explored in future work. We also demonstrated that SGE does not inhibit proliferation if memory cells are generated to other antigens. For example, spleen cells from An. aquasalis-sensitized mice proliferate when cultured with SGE of the same species, even in the presence of $A$. aegypti SGE. In addition, when these cells are co-cultured with Con A plus $A$. aegypti SGE, the inhibition of the proliferative response is only partial, reinforcing again our assumption that only naïve cells are affected by the presence of SGE in culture (Figure 5C).

This hypothesis is further supported by analyzing the proliferation of spleen cells from BALB/c mice receiving cells from a DO11.10 donor and subsequently immunized with OVA. When these cells are co-cultured with Con A plus $\mathrm{SGE}$, the proliferation is partially inhibited (Figure $5 \mathrm{~B}$ ), whereas in cells from non-sensitized animals, SGE completely inhibits proliferation (Figure 5A). Remarkably, antigen-specific proliferation induced by OVA only occurs in sensitized mice, as expected, and it is not affected by $A$. aegypti SGE (Figure 5D and 5E). Regarding cell phenotype, SGE affects naive cells $\left(\mathrm{CD} 62 \mathrm{~L}^{\mathrm{HIGH}}\right.$ / CD $44^{\mathrm{LOW}}$ ) in both, control and immunized animals (Figure 5F and Figure 5G, respectively), while $\mathrm{T}_{\mathrm{CM}}$ cells $\left(\mathrm{CD} 62 \mathrm{~L}^{\mathrm{HIGH}} / \mathrm{CD} 44^{\mathrm{HIGH}}\right)$ and $\mathrm{T}_{\mathrm{EM}}$ cells $\left(\mathrm{CD} 62 \mathrm{~L}^{\mathrm{LOW}} /\right.$ $\mathrm{CD} 44^{\mathrm{HIGH}}$ ) are proportionally more resistant in immunized animals (Figure 5G). So far, there is a single study showing a selective action of a salivary component in subpopulations of T cells. Such work demonstrated that Salp15, from the I. scapularis tick, binds to CD4 but not CD8 T cell co-receptor [50]. However, this is the first time that arthropod saliva has been shown to discriminate between naïve and memory $\mathrm{T}$ cells.

The blood feeding strategies greatly diverge between many hematophagous arthropods. While hard ticks maintain prolonged contact with host skin, some others, like mosquitoes and sandflies, are transient feeders and leave their host in minutes or even seconds. Undoubtedly, their strategies to modulate the host vascular and immune system may vary as well.

\section{Conclusions}

Together, these results provide evidence for a complex interaction between $A$. aegypti salivary constituents and the host immune system. This pioneer study shows that saliva of a hematophagous arthropod is able to distinguish among different cell types (dendritic cells versus lymphocytes) and even subpopulations of the same cell type (naïve versus memory $\mathrm{T}$ cells). Whether this selectivity is important to mosquitoes feeding and reproduction remains to be determined. Therefore, the results generated by this work contributes to clarifying some of the features of the vector-host interaction providing a better understanding of the mechanisms used by the mosquito A. aegypti to circumvent the immune system of their hosts and successfully feed.

\section{Additional files}

Additional file 1: A. aegypti SGE inhibits T cell proliferation. BMDC were pre-incubated with medium or $40 \mu \mathrm{g} / \mathrm{mL}$ of $A$. aegypti SGE overnight, washed 3 times and co-incubated with $\mathrm{CD}^{+}$from D011.10 mice stained with CFSE. A. aegypti SGE was replaced in culture after washing and T cells 
were stimulated with Con A for $72 \mathrm{~h}$. Cells were evaluated by flow cytometry as described in Methods.

\section{Additional file 2: $A$. aegypti SGE induces changes in total spleen} cell phenotype. Indirect evaluation of the cell viability by examining the size (FSC) and internal complexity (SSC) of spleen cells incubated with Con A (B-G) for $72 \mathrm{~h}$ in the presence of increasing concentrations of $\mathrm{A}$. aegypti $\operatorname{SGE}(0.1,0.5,1,5$ and $10 \mu \mathrm{g} / \mathrm{mL})$ and compared with fresh cells (A).

Additional file 3: Antibodies produced by B lymphocytes do not neutralize SGE activity. Three-day culture supernatants from different numbers of spleen cells from non-sensitized (A) and A. aegypti-sensitized (B) mice were used as a conditioned medium for cell cultures from a control mice spleen. These cells were then pre-incubated with medium alone or A. aegypti SGE and then stimulated with Con A for $72 \mathrm{~h}$.

\section{Additional file 4: Memory cells are resistant to $A$. aegypti SGE} effects. Non-adherent D011.10 spleen cells were adoptively transferred to BALB/C mice and after 7 days, recipient mice were sensitized with OVA and complete Freund's adjuvant ( $40 \mathrm{\mu g} / \mathrm{animal})$. Spleen cells from non-sensitized and sensitized mice were obtained after 7 days and cultured in the presence of medium or A. aegypti SGE and stimulated with Con A (0.5 $\mu \mathrm{g} / \mathrm{mL}$ ) or OVA (100 $\mu \mathrm{g} / \mathrm{mL})$. Phenotype of naïve cells (CD62 $\mathrm{L}^{\mathrm{HIGH}} / \mathrm{CD} 44^{\mathrm{LOW}}$ ), $\mathrm{T}_{\text {EM }}$ subset (CD62 $\mathrm{L}^{\mathrm{LOW}}$ and $\mathrm{CD} 44^{\mathrm{HIGH}}$ ) and $\mathrm{T}_{\mathrm{CM}}$ subset (CD62 $\mathrm{L}^{\mathrm{HIGH}}$ and $\mathrm{CD} 44^{\mathrm{HIGH}}$ ) from non-sensitized or sensitized mice were evaluated by flow cytometry after $72 \mathrm{~h}$ cultured in presence of medium or A. aegypti SGE and stimulated with Con A or OVA.

\section{Abbreviations}

SGE: Salivary gland extract; FSDC: Fetal skin-derived DC line; BMDC: Bone marrow-derived dendritic cell; PGE : Prostaglandin $\mathrm{E}_{2} ;$ 5'AMP: Adenosine monophosphate..

\section{Competing interests}

The authors declare that they have no competing interests.

\section{Authors' contributions}

$\mathrm{BB}, \mathrm{MK}, \mathrm{GPAM}, \mathrm{EC}, \mathrm{MLC}$ and AS-N conceived the experimental design and assisted data interpretation. BB, MSB, CM, DIG, CNL, JC, MLC and AS-N carried out laboratory work. BB and AS-N wrote the manuscript's draft. All authors read, reviewed and approved the final manuscript.

\section{Acknowledgments}

The authors would like to thank Dr. Momtchilo Russo and Dr. Sonia Jancar (Department of Immunology, ICB/USP, Brazil) for providing some reagents and equipments used in this work; Dr. Philippe Bouillet (Walter and Elisa Hall Institute of Medical Research, Australia) for providing the $\mathrm{BIM}^{-/-}$mice; and Dr. José M. Ribeiro (Laboratory of Malaria and Vector Research, NIAID/ $\mathrm{NIH}$, USA) for encouragement and support. The authors also thank Van M. Pham (Laboratory of Malaria and Vector Research, NIAID/NIH, USA) and Sandra Alexandre (Department of Immunology, ICB/USP) for their technical assistance. The following authors were recipients of fellowships: B.B. (FAPESP 2009/12247-5); M.S.B. (CNPq 134660/2010-2); C.M. (FAPESP 2010/ 18216-1); D.I.G. (FAPESP 2011/06626-3); C.N.L. (FAPESP 2011/15569-3). This work was supported by grants from FAPESP (2009/09892-6 and 2009/ 53637-0), CNPq (302194/2009-6), Casadinho/PROCAD (MCTI/CNPq/MEC/ CAPES 552258/2011-3), Brazilian Malaria Network (MCT/CNPq/MS/SCTIE/ DECIT/PRONEX 555648/2009-5), and Research Network on Bioactive Molecules from Arthropod Vectors (NAP-MOBIARVE, University of São Paulo). We dedicated this paper to the memory of Alexandre A. Peixoto.

\section{Author details}

${ }^{1}$ Laboratório de Imunologia Experimental, Departamento de Imunologia, Instituto de Ciências Biomédicas, Universidade de São Paulo, São Paulo 05508-900, SP, Brazil. ² Laboratório de Biologia Celular e Molecular,

Departamento de Imunologia, Instituto de Ciências Biomédicas, Universidade de São Paulo, São Paulo, SP 05508-900, Brazil. ${ }^{3}$ Laboratory of Genomics and Proteomics of Disease Vectors, Institute of Parasitology, Biology Centre of the Academy of Sciences of Czech Republic, Ceske Budejovice 37005, Czech Republic. ${ }^{4}$ Instituto de Investigação em Imunologia, Instituto Nacional de Ciência e Tecnologia, INCT, São Paulo, Brazil. ${ }^{5}$ Section of Vector Biology, Laboratory of Malaria and Vector Research, National Institute of Allergy and
Infectious Diseases, National Institutes of Health, Rockville, MD 20852, USA 'Laboratório de Mosquitos Geneticamente Modificados, Departamento de Parasitologia, Instituto de Ciências Biomédicas, Universidade de São Paulo, São Paulo, SP 05508-900, Brazil. ' Instituto Nacional de Ciência e Tecnologia em Entomologia Molecular, Conselho Nacional de Desenvolvimento Científico e Tecnológico (INCT-EM/CNPq), Rio de Janeiro, Brazil.

Received: 28 September 2013 Accepted: 5 November 2013 Published: 15 November 2013

\section{References}

1. Morens DM, Folkers GK, Fauci AS: The challenge of emerging and re-emerging infectious diseases. Nature 2004, 430(6996):242-249.

2. Tolle MA: Mosquito-borne diseases. Curr Probl Pediatr Adolesc Health Care 2009, 39(4):97-140.

3. Scott TW, Takken W: Feeding strategies of anthropophilic mosquitoes result in increased risk of pathogen transmission. Trends Parasito/ 2012 28(3):114-121.

4. Fontaine A, Diouf I, Bakkali N, Misse D, Pages F, Fusai T, Rogier C, Almeras L: Implication of haematophagous arthropod salivary proteins in hostvector interactions. Parasit Vectors 2011, 4:187.

5. Francischetti IM, Sa-Nunes A, Mans BJ, Santos IM, Ribeiro JM: The role of saliva in tick feeding. Front Biosci 2009, 14:2051-2088.

6. Ribeiro JM, Francischetti IM: Role of arthropod saliva in blood feeding sialome and post-sialome perspectives. Annu Rev Entomol 2003, 48:73-88.

7. Edwards JF, Higgs S, Beaty BJ: Mosquito feeding-induced enhancement of Cache Valley Virus (Bunyaviridae) infection in mice. J Med Entomol 1998, 35(3):261-265.

8. Limesand $\mathrm{KH}$, Higgs $\mathrm{S}$, Pearson LD, Beaty BJ: Effect of mosquito salivary gland treatment on vesicular stomatitis New Jersey virus replication and interferon alpha/beta expression in vitro. J Med Entomo/ 2003, 40(2):199-205.

9. Schneider BS, Soong L, Coffey LL, Stevenson HL, McGee CE, Higgs S: Aedes aegypti saliva alters leukocyte recruitment and cytokine signaling by antigen-presenting cells during West Nile virus infection. PLoS One 2010, 5(7):e11704

10. Styer LM, Bernard KA, Kramer LD: Enhanced early West Nile virus infection in young chickens infected by mosquito bite: effect of viral dose. Am J Trop Med Hyg 2006, 75(2):337-345.

11. Styer LM, Lim PY, Louie KL, Albright RG, Kramer LD, Bernard KA: Mosquito saliva causes enhancement of West Nile virus infection in mice. J Virol 2011, 85(4):1517-1527.

12. Surasombatpattana P, Patramool S, Luplertlop N, Yssel H, Misse D: Aedes aegypti Saliva Enhances Dengue Virus Infection of Human Keratinocytes by Suppressing Innate Immune Responses. J Invest Dermatol 2012 132(8):2103-2105.

13. Machain-Williams C, Mammen MP Jr, Zeidner NS, Beaty BJ, Prenni JE, Nisalak A, Blair CD: Association of human immune response to Aedes aegypti salivary proteins with dengue disease severity. Parasite Immunol 2012, 34(1):15-22.

14. Schneider BS, Higgs S: The enhancement of arbovirus transmission and disease by mosquito saliva is associated with modulation of the host immune response. Trans R Soc Trop Med Hyg 2008, 102(5):400-408.

15. Banchereau J, Steinman RM: Dendritic cells and the control of immunity. Nature 1998, 392(6673):245-252.

16. Wasserman HA, Singh S, Champagne DE: Saliva of the Yellow Fever mosquito, Aedes aegypti, modulates murine lymphocyte function. Parasite Immunol 2004, 26(6-7):295-306.

17. Cross ML, Cupp EW, Enriquez FJ: Differential modulation of murine cellular immune responses by salivary gland extract of Aedes aegypti. Am J Trop Med Hyg 1994, 51(5):690-696.

18. Wanasen N, Nussenzveig RH, Champagne DE, Soong L, Higgs S: Differential modulation of murine host immune response by salivary gland extracts from the mosquitoes Aedes aegypti and Culex quinquefasciatus. Med Vet Entomol 2004, 18(2):191-199.

19. Boppana VD, Thangamani S, Adler AJ, Wikel SK: SAAG-4 is a novel mosquito salivary protein that programmes host CD4 T cells to express IL-4. Parasite Immunol 2009, 31(6):287-295.

20. Zeidner NS, Higgs S, Happ CM, Beaty BJ, Miller BR: Mosquito feeding modulates Th1 and Th2 cytokines in flavivirus susceptible mice: an effect mimicked by injection of sialokinins, but not demonstrated in flavivirus resistant mice. Parasite Immunol 1999, 21(1):35-44. 
21. Opal SM, Esmon CT: Bench-to-bedside review: functional relationships between coagulation and the innate immune response and their respective roles in the pathogenesis of sepsis. Crit Care 2003, 7(1):23-38.

22. Niessen F, Schaffner F, Furlan-Freguia C, Pawlinski R, Bhattacharjee G, Chun J, Derian CK, Andrade-Gordon P, Rosen H, Ruf W: Dendritic cell PAR1-S1P3 signalling couples coagulation and inflammation. Nature 2008, 452(7187):654-658.

23. Ruf W, Furlan-Freguia C, Niessen F: Vascular and dendritic cell coagulation signaling in sepsis progression. J Thromb Haemost 2009, 7(Suppl 1):118-121.

24. Sa-Nunes A, Bafica A, Lucas DA, Conrads TP, Veenstra TD, Andersen JF, Mather TN, Ribeiro JM, Francischetti IM: Prostaglandin E2 is a major inhibitor of dendritic cell maturation and function in Ixodes scapularis saliva. J Immunol 2007, 179(3):1497-1505.

25. Carregaro V, Sa-Nunes A, Cunha TM, Grespan R, Oliveira CJ, Lima-Junior DS, Costa DL, Verri WA Jr, Milanezi CM, Pham VM, et al: Nucleosides from Phlebotomus papatasi salivary gland ameliorate murine collageninduced arthritis by impairing dendritic cell functions. J Immuno/ 2011 187(8):4347-4359

26. Collin N, Assumpcao TC, Mizurini DM, Gilmore DC, Dutra-Oliveira A, Kotsyfakis M, Sa-Nunes A, Teixeira C, Ribeiro JM, Monteiro RQ, et al: Lufaxin, a novel factor Xa inhibitor from the salivary gland of the sand fly Lutzomyia longipalpis blocks protease-activated receptor 2 activation and inhibits inflammation and thrombosis in vivo. Arterioscler Thromb Vasc Biol 2012, 32(9):2185-2198.

27. Sa-Nunes A, Bafica A, Antonelli LR, Choi EY, Francischetti IM, Andersen JF, Shi GP, Chavakis T, Ribeiro JM, Kotsyfakis M: The immunomodulatory action of sialostatin $L$ on dendritic cells reveals its potential to interfere with autoimmunity. J Immunol 2009, 182(12):7422-7429.

28. Ahmed SA, Gogal RM Jr, Walsh JE: A new rapid and simple non-radioactive assay to monitor and determine the proliferation of lymphocytes: an alternative to [3H]thymidine incorporation assay. J Immunol Methods 1994, 170(2):211-224.

29. Wojciechowski S, Tripathi P, Bourdeau T, Acero L, Grimes HL, Katz JD, Finkelman FD, Hildeman DA: Bim/Bcl-2 balance is critical for maintaining naive and memory T cell homeostasis. J Exp Med 2007, 204(7):1665-1675

30. Kurtulus S, Tripathi $P$, Hildeman DA: Protecting and rescuing the effectors: roles of differentiation and survival in the control of memory $T$ cell development. Front Immunol 2012, 3:404.

31. Dutton RW, Bradley LM, Swain SL: T cell memory. Annu Rev Immunol 1998, $16: 201-223$

32. Reinhardt RL, Khoruts A, Merica R, Zell T, Jenkins MK: Visualizing the generation of memory CD4 T cells in the whole body. Nature 2001, 410(6824):101-105.

33. Masopust $D$, Vezys $V$, Marzo AL, Lefrancois L: Preferential localization of effector memory cells in nonlymphoid tissue. Science 2001, 291(5512):2413-2417.

34. Sallusto F, Lenig D, Forster R, Lipp M, Lanzavecchia A: Two subsets of memory $T$ lymphocytes with distinct homing potentials and effector functions. Nature 1999, 401(6754):708-712.

35. Medeiros Al, Sa-Nunes A, Turato WM, Secatto A, Frantz FG, Sorgi CA, Serezani $\mathrm{CH}$, Deepe GS Jr, Faccioli LH: Leukotrienes are potent adjuvant during fungal infection: effects on memory T cells. J Immunol 2008, 181(12):8544-8551.

36. Lehane M: The Biology of Blood-Sucking in Insects. 2nd edition. Cambridge: Cambridge University Press; 2005.

37. Cavassani KA, Aliberti JC, Dias AR, Silva JS, Ferreira BR: Tick saliva inhibits differentiation, maturation and function of murine bone-marrow-derived dendritic cells. Immunology 2005, 114(2):235-245.

38. Poole NM, Mamidanna G, Smith RA, Coons LB, Cole JA: Prostaglandin E2 in tick saliva regulates macrophage cell migration and cytokine profile. Parasit Vectors 2013, 6(1):261.

39. Oliveira CJ, Sa-Nunes A, Francischetti IM, Carregaro V, Anatriello E, Silva JS, de Miranda Santos IK, Ribeiro JM, Ferreira BR: Deconstructing tick saliva: non-protein molecules with potent immunomodulatory properties. J Biol Chem 2011, 286(13):10960-10969.

40. Chen G, Severo MS, Sohail M, Sakhon OS, Wikel SK, Kotsyfakis M, Pedra JH: Ixodes scapularis saliva mitigates inflammatory cytokine secretion during Anaplasma phagocytophilum stimulation of immune cells. Parasit Vectors 2012, 5:229.

41. Brake DK, Perez de Leon AA: Immunoregulation of bovine macrophages by factors in the salivary glands of Rhipicephalus microplus. Parasit Vectors 2012, 5:38
42. Hovius JW, de Jong MA, den Dunnen J, Litjens M, Fikrig E, van der Poll T, Gringhuis SI, Geijtenbeek TB: Salp15 binding to DC-SIGN inhibits cytokine expression by impairing both nucleosome remodeling and mRNA stabilization. PLoS Pathog 2008, 4(2):e31.

43. Costa DJ, Favali C, Clarencio J, Afonso L, Conceicao V, Miranda JC, Titus RG Valenzuela J, Barral-Netto M, Barral A, et al: Lutzomyia longipalpis salivary gland homogenate impairs cytokine production and costimulatory molecule expression on human monocytes and dendritic cells. Infect Immun 2004, 72(3):1298-1305.

44. Carregaro V, Valenzuela JG, Cunha TM, Verri WA Jr, Grespan R, Matsumura G, Ribeiro JM, Elnaiem DE, Silva JS, Cunha FQ: Phlebotomine salivas inhibit immune inflammation-induced neutrophil migration via an autocrine DC-derived PGE2/IL-10 sequential pathway. J Leukoc Biol 2008, 84(1):104-114

45. Merad M, Sathe P, Helft J, Miller J, Mortha A: The dendritic cell lineage: ontogeny and function of dendritic cells and their subsets in the steady state and the inflamed setting. Annu Rev Immunol 2013, 31:563-604

46. Merad M, Ginhoux F, Collin M: Origin, homeostasis and function of Langerhans cells and other langerin-expressing dendritic cells. Nat Rev Immunol 2008, 8(12):935-947.

47. Oliveira CJ, Sa-Nunes A, Francischetti IM, Carregaro V, Anatriello E, Silva JS, Santos IK, Ribeiro JM, Ferreira BR: Deconstructing tick saliva: non-protein molecules with potent immunomodulatory properties. J Biol Chem 2011 286(13):10960-10969.

48. Tsujimoto H, Gray EW, Champagne DE: Black fly salivary gland extract inhibits proliferation and induces apoptosis in murine splenocytes. Parasite Immunol 2010, 32(4):275-284.

49. Sutherland $G B$, Ewen $A B$ : Fecundity decrease in mosquitoes ingesting blood from specifically sensitized mammals. J Insect Physiol 1974, 20(4):655-660.

50. Garg R, Juncadella IJ, Ramamoorthi Ashish N, Ananthanarayanan SK, Thomas $V$, Rincon M, Krueger JK, Fikrig E, Yengo CM: Cutting edge: CD4 is the receptor for the tick saliva immunosuppressor, Salp15. J Immunol 2006, 177(10):6579-6583.

doi:10.1186/1756-3305-6-329

Cite this article as: Bizzarro et al.: Effects of Aedes aegypti salivary components on dendritic cell and lymphocyte biology. Parasites \& Vectors 2013 6:329.

\section{Submit your next manuscript to BioMed Central and take full advantage of:}

- Convenient online submission

- Thorough peer review

- No space constraints or color figure charges

- Immediate publication on acceptance

- Inclusion in PubMed, CAS, Scopus and Google Scholar

- Research which is freely available for redistribution 